\title{
A DÉL-DUNÁNTÚl A PIACGAZDASÁGI ÁTMENETBEN
}

\author{
(South Transdanubia on Its Way towards the Market Economy)
}

\section{NEMES NAGY JÓZSEF}

A rendszerváltozás folyamatai a társadalom egészét átformálják, hatásai érintik a legkisebb települést is. A változásoknak ugyanakkor nyilvánvaló jellemvonása a térségi és települési tagoltság. Ez elsõsorban a gazdasági változások dinamikahordozó elemeiben (új vállalkozások, külföldi tôke) jelentkezik. A válságjegyekben inkább csak kisebb-nagyobb intenzitási különbségek, mintsem minôségi eltérések mérhetốk a kilencvenes évek elejének átfogó recesszióján belül. A gazdasági válságjelenségek (munkanélküliség, csôdök, veszteséges termelés, elavult, túlterhelt infrastruktúra, környezeti károk) szétterültsége alapozza meg - nehezen cáfolható módon - azokat a vélekedéseket, amelyek az ország szinte minden térségét támogatásra szoruló válságterületnek tartják. A regionális gazdasági folyamatok elemzései - a rendelkezésre álló fejlesztési források köztudott szűkösségének kimondatlan tudomásulvételével a háttérben - jellemzõen mégis hangsúlyozott különbséget tesznek, ami sajnálatosan csak a viszonylagos dinamika térségei és a legmélyebb gazdasági krízissel küszködố régiók között érzékelhetố. Ezek a vizsgálatok relatíve kedvezô helyzetũ térségként a központi, fôváros körüli térséget és az északnyugati országrészt jelölik meg, s a nagyrégiók közül az északi megyék és a Tiszától keletre fekvô vidék képezik a válságtérségeket.

Az egységes nagyrégióként vizsgált Dél-Dunántúl egyik ,,szélsô”’ csoportba sem sorolódik be. Mit jelent ez? Arcnélküliséget, problémamentességet, netán csupán az ismerethiány csalfa magabiztossága eredményezi ezt a minõsítést? Tanulmányunk e kérdések megválaszolásához próbál néhány adalékot közreadni a távoli szemlélố mindenképp indokolt szerénységére törekedve az ítéletalkotásban.

Alapkarakterét tekintve egy rövid regionális gazdaságstatisztikai elemzést adunk közre, ami nem pótolja a régió szinte naponta változó gazdasági viszonyainak, gazdasági folyamatainak a konkrét helyi ismerteken, tapasztalatokon nyugvó analízisét, ahhoz inkább csak hátteret nyújt.

Megtakarítandó a késôbbi - az Olvasót vélhetôen kevésbé érdekló - többszöri hivatkozást az információs, módszertani problémákra a felhasznált adatok jellegérôl és forrásairól, a legalapvetôbb ismérveket már itt összefoglaljuk. Az elemzett adatok 1992., illetve 1991. évre vonatkoznak (a regionális gazdasági elemzések a konszolidált gazdaságú és statisztikai rendszerũ országokban is jellemzõen két-három éves késésben vannak). Az elemzés a régió egészét, a négy megyét, illetve a kisebb körzeteket az alábbi fontosabb adatok tükrében vizsgálja: 
- gazdasági szereplók (cégek, vegyesvállalatok, egyéni vállalkozók) megoszlása, sũrũsége;

- gazdasági eredménymutatók (hozzáadott érték, eredmény, exportorientáció);

- adóköteles jövedelmek.

Többször említjük a munkanélküliséget; mint alapvetõ indikátorát a regionális gazdasági helyzetnek, mivel azonban e témakörrel a TÉT jelen számában önálló tanulmány foglalkozik, részletekbe menó analízisét a munkanélküliségnek nem szerepeltetjük. A cégekre (gazdasági társaságok, vállalatok, szövetkezetek) vonatkozó adatok az 1992. évi társasági nyereségadó bevallásokból kerültek aggregálásra, ezek mindegyike székhely szerinti adat. A személyi jövedelemadó-statisztikákból származó adóköteles jövedelmek adatai az adózók lakóhelye szerint számba vettek. (E két adatbázist a szerzó állította össze a PM GII-ben, a PSZTI, illetve az APEH adatbázisaiból). Az egyéni vállalkozókra vonatkozó adatok a KSH TSTAR adatbázisából származnak. Az alapadatokból többféle relatív mutató, illetve komplex index került kiszámításra és elemzésre.

Az adatelemzésbõl általunk levonhatónak vélt regionális politikai következtetésekkel, a térségi fejlesztési koncepció jellegét és tartalmát érintố megállapításokkal zárjuk a tanulmányt.

\section{A Dél-Dunántúl gazdasági súlya és pozíciói az országon belül}

A négy megyét átfogó makrorégió az ország legnagyobb területi kiterjedésũ nagytérsége. Területi kiterjedésénél kisebb népességi és gazdasági súlya, azaz mind a népsũrũség mind a gazdasági sưrúség mutatói elmaradnak az átlagtól. A hazai gazdaságnak mintegy egy tizede, a vidéki gazdasági potenciálnak 15-20 százaléka található a régióban.

A gazdasági jelzôszámok túlnyomó többsége a régiót az országos átlag körüli, de a vidéki átlagnál jobb gazdasági helyzetũ térségnek minôsítik (1. táblázat). A DélDunántúl gazdasági jegyei a kilencvenes évek elején szinte minden tekintetben kedvezổbbek a keleti és északi országrészénél, általában alatta maradnak az északnyugati térség mutatóinak, s messze elmaradnak az országból kiemelkedó központi térségétôl. Ettổ a minósítéstổ csak néhány jelzószám tér el. Pozitív irányú az eltérés az egyéni vállalkozók népességre vetített száma tekintetében, amiben a térség a vidéken belül messze kiemelkedik, $\mathrm{s}$ megközelíti a fôvárost. Ellentétes irányú eltérést mutat a térségbe települt cégek exportorientációja, amely a legkevésbé nyitott gazdasági szerkezetre utal az országban. A táblázatban közölt mutatószámok közül egyedül a cégek árbevételarányos eredménye (helyesebben vesztesége) töri meg a térség kiemelkedõ gazdasági pozíciójára utaló számos jelet, ami egyben az ország egészére jellemzô kritikus gazdasági 


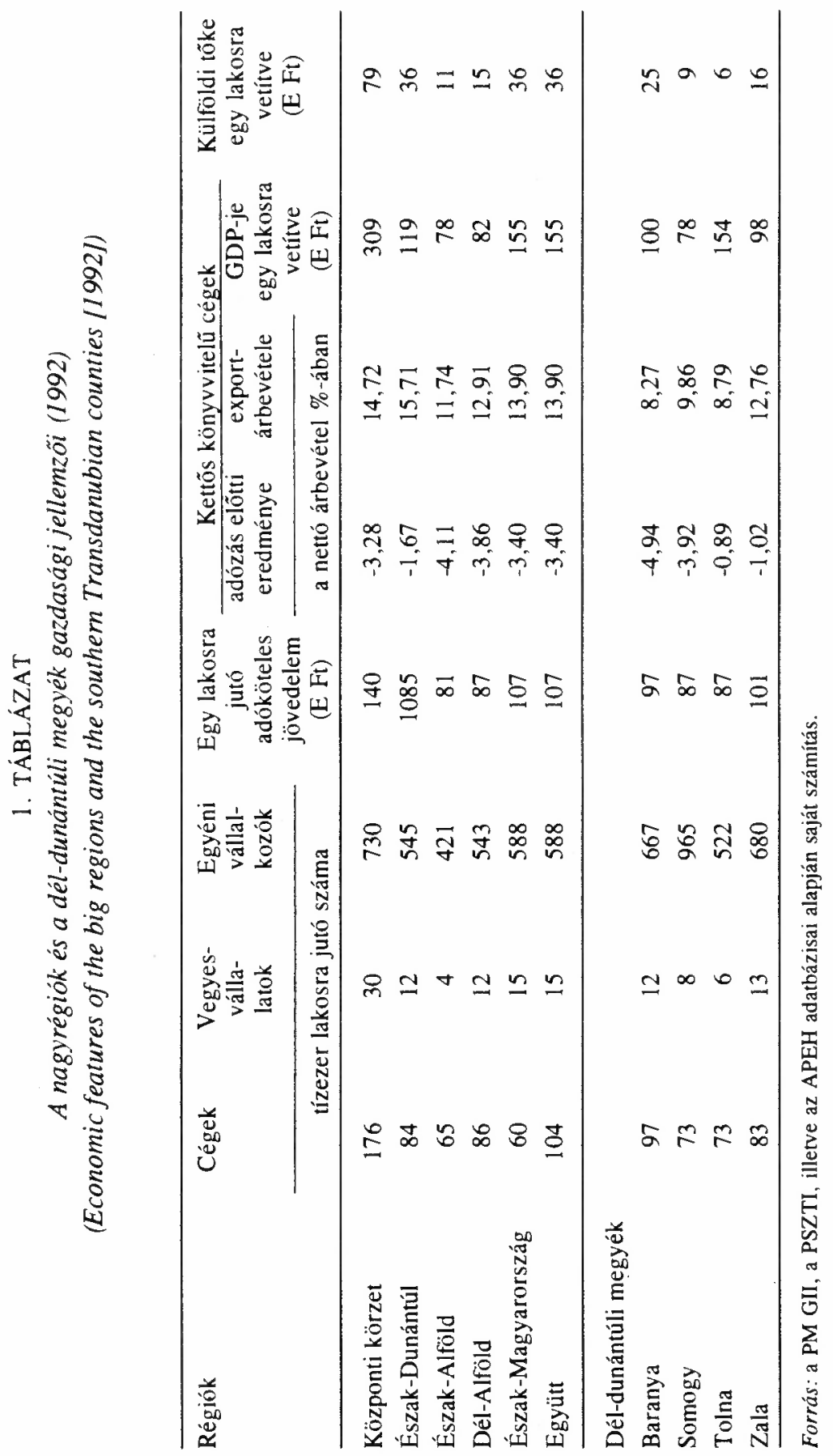


szituációt is szembetũnõen mutatja. A Dél-Dunántúl e jelzốszámban is átlagos pozíciójú. Az itt közölt gazdasági tényadatokon túlmenôen a jelzett gazdasági súlyt és az átlag körüli pozíciót megerôsítik azok a jeienleg folyó számítási munkák is, amelyek a gazdaság egészére vonatkozóan megkísérlik a regionális GDP meghatározását. Ezek elsõ eredményei szerint a Dél-Dunántúlon 1992-ben az összes GDP mintegy $300 \mathrm{Mrd}$ Ft-ot tett ki (az országos volumen $2451 \mathrm{Mrd} F \mathrm{Ft}$ ), az egy lakosra jutó becsült GDP nagysága az országos átlag $96 \%$-án állt.

\section{A dél-dunántúli megyék gazdasági jellemzôi}

Nem fordít nagyot a régió egészének helyzetét minõsítô megállapításokon a megyei szintũ elemzés sem. Nincs ugyanis a térségben egyetlen megye sem, amely messze kiemelkedne illetve lemaradna. A régióban megyei szinten nincs fejlettségi hierarchia. A különbözô gazdasági jelzószámokban más-más megye kerül a legkedvezóbb, illetve legkedvezốtlenebb helyzetbe (1. táblázat). Baranya a cégsürüségben és a befektetett külföldi tổke relatív nagyságában vezeti a megyesort, Somogyban az országban a legmagasabb az egyéni vállalkozók relatív létszáma, Tolnában viszonylag a legkedvezõbb az eredményességi mutató és itt a legmagasabb az egy lakosra jutó vállalati GDP. Zala a vegyesvállalatok relatív számában, az átlagos adóköteles jövedelmekben, illetve az exportorientáció mutatójában áll az élen. A gazdasági modernizációs elemeket faktoranalízissel komplex mutatóba foglaló közelmúltbeli vizsgálataink ${ }^{1}$ szerint is mind a négy megye az országos átlag körüli ,,gazdasági egészségư”', Zala, Somogy, Baranya, Tolna sorrendben, de szignifikáns különbség nélkül.

$\mathrm{Az}$ a kijelentés, hogy a régióban nincs a megyék között éles fejlettségi tagoltság nem jelenti feltétlenül azt, hogy gazdasági karakterük is azonos. Az a tény, hogy a négy megye közül az egyes gazdasági jelzôszámokban más és más kerül az élre, épp a gazdasági szerkezet eltéréseire utal. Ezek az eltérések azonban igazából csak a kistérségi szintũ elemzésekben kerülnek felszínre, a megyei átlagok csak sejtetik a differenciákat.

\section{Kistérségi különbségek a régió gazdaságában}

Ha a régió gazdaságát kistérségi szinten elemezzük, az elôzõekben elmondottaktól alapvetốen eltérố következtetésre jutunk, amelynek lényege az, hogy a Dél-Dunántúl az ország egyik legsokszínúbb, legtagoltabb gazdasági karakterü makrorégiója.

Ez a kijelentés a gazdasági térképekre tekintve vagy a vidéket bejárva szinte nyilvánvaló, de ha nem elégszünk meg a ,,ránézésre" történô igazolással, többféle úton is eljárhatunk. A sokszínũség, az erốs kistérségi tagoltság mennyiségi kategóriákra lefordítva azt a hipotézist jelenti, hogy e gazdasági jelzôszámok kistérségi differenciálódása 
a Dél-Dunántúlon nagyobb, mint más térségekben. Az országot - általánosan elfogadott kistérségi felosztás híján - 318 kistérségre bontva megvizsgáltuk néhány gazdasági jelzôszám relatív szóródását (2. táblázat).

A számítási eredmények alapvetôen igazolják a hipotézist. A táblázatban szereplõ különbözô gazdasági tartalmakat lefedô - hat mutatószám közül háromban a dél-dunántúli szórásmutató a legmagasabb. Mikrokörzeti szinten ez a régió a legtagoltabb az egyéni vállalkozások eloszlása, az iparosodottság tekintetében, s 1992 nyarán itt volt a legdifferenciáltabb a munkanélküliségi ráta is. A többi jelzôszámban is erốs tagoltságot jeleznek a számítások. A cégsũrũségben csak az Észak-Alföld tagoltsága nagyobb, a vegyesvállalatok eloszlása és az adóköteles jövedelmek mutatójában is csak a két alföldi régió differenciáltabb. (Nagyon elkanyarodnánk alaptémánktól, ha itt részleteiben elemeznénk az alföldi kistérségi differenciáltság jellegét, így csak arra utalunk, hogy elsődlegesen a két legnagyobb regionális centrum, Szeged és Debrecen kiemelkedõen kedvezố mutatói okozzák a nagy szórást). A Dél-Dunántúl minden jelzôszám tekintetében tagoltabb az Észak-Dunántúlnál, a Központi körzetnél és Észak-Magyarországnál. (A táblázat kapcsán épp csak utalunk arra, hogy a benne szereplõ értékek nagyságviszonyai nemcsak a régiókat, hanem az egyes mutatószámokat összevetve is érdekes megállapításokra vezetnek. Jól látszik az, hogy a jövedelemmutató viszonylagosan mennyire kiegyenlített, a munkanélküliségi ráta szóródása is e válságjegy erôteljes diffúzióját jelzi, kiugróan differenciált ugyanakkor a vegyesvállalatok eloszlása, s a visszaszorulóban lévõ ipari foglalkoztatottság is).

A gazdasági jelzõszámok magas szórásindexei nagyon eltérõ gazdasági karakterũ kistérségek jelenlétére utalnak. Ezek feltárása, kijelölése sokféle úton-módon végrehajtható. A tanulmány tartalmi-módszertani alapvonalán haladva e térségtípusokat egy az ország egészére kiterjedô többváltozós matematikai-statisztikai elemzés tükrében mutatjuk be.

Az elemzés induló hipotézise az volt, hogy a mai regionális gazdasági folyamatokat a piacgazdasági átmenet struktúraátalakító, modernizációs mozgásai és a meglévô tradicionális gazdasági szerkezet regionális dualizmusa határozza meg. E hipotézisbõl kiindulva 318 mikrokörzetre vonatkozóan elvégeztünk egy faktorelemzést, amelyben alapadatként a cégsũrũség, a vegyesvállalatok, illetve az egyéni vállalkozók relatív számának 1992. évre vonatkozó mutatóit, a munkanélküliségi ráta 1992. júliusi becsült értékeit, az egy lakosra jutó 1991. évi adóköteles jövedelmek adatát és az ipari foglalkoztatottak népességre vetített 1992. évi számát vontuk be. A faktorelemzés két fôfaktort eredményezett, amelyek egyike a fentiekben felsorolt elsố négy, a másik pedig az utóbbi két jelzôszámmal korrelált erôsen. (A számítási részeredmények közlésétôl itt eltekintünk.) A matematikai analizis egyértelmũen igazolta tehát a feltételezett kettósséget, hisz épp a modernizáció-tradicionális struktúra dimenziók mentén , ,vágta ketté" az adatrendszert, egy mutatóba összegezve a vállalkozási aktivitás, a privatizáció, valamint a munkanélküliség jelzôszámait (ez utóbbit negativv előjellel), illetve az iparosodottságét 


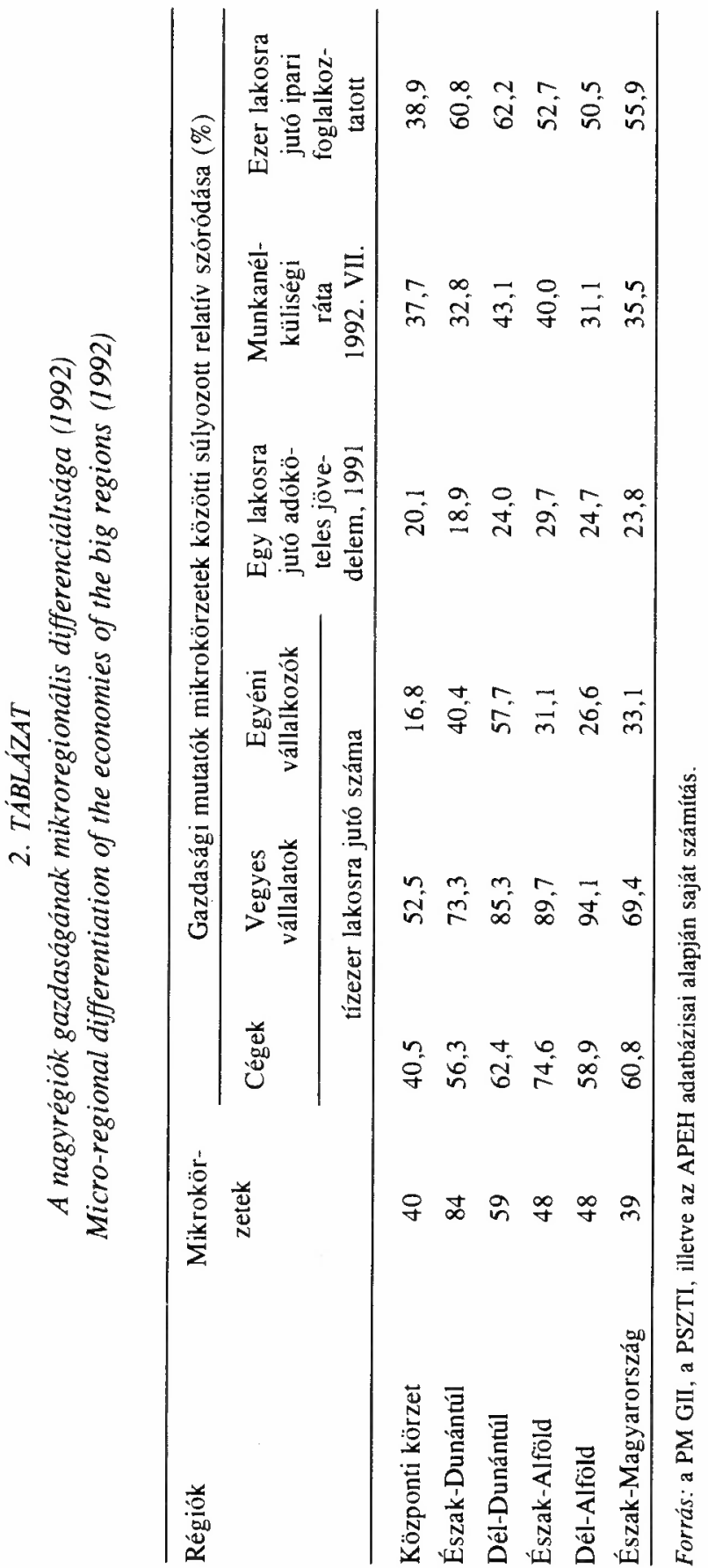


és az adóköteles jövedelmekét, ami köztudottan épp a hagyományos nagyszervezetek alkalmazottai béreihez kötôdố jelzốszám.

A két faktor értékeit (MODERDIN illetve IPARKONC elnevezéssel) egymással kombinálva vittük térképre (1. ábra), kilenc típust kijelölve a két dimenzió párosításával. Az elemzés látványosan tagolja az országot: a központi és nyugati országrészben összpontosulnak a modernizációban leginkább elórehaladott térségek, míg a keleti-északkeleti térség - a legnagyobb városokat kivéve - sem ebben a tényezốben, sem a tradicionális gazdasági (ipari) fejlettséget jelzô mutatóban nem kap kedvezõ értékelést.

A Dél-Dunántúl mikrorégiói közül a négy megyeszékhely mindkét dimenzióban az országos átlag fölé kerül. Ezek tekinthetốk a legperspektivikusabb körzeteknek. Mindegyikre jellemzõ ugyanakkor az, hogy körülöttük nem mutatható ki markáns agglomerációs tendencia, a környezó térségek nem kölcsönösen kapcsolódnak e központokhoz, hanem azoktól függnek, kiemelkedô gazdasági erejüknek alárendeltek. Különösen igaz ez a régió legnagyobb központjára, Pécsre. Három körzet (Nagykanizsa, Komló és Paks) esetében a modernizációs elemek csak átlagosak, míg a tradicionális (ipari) elemek súlya kiemelkedik. Paks jellegzetes energetikai enklávéja a térségnek, Komló pedig tipikus depressziós térség. A nagyrégió - országos relációban is - legsajátosabb térsége a Balaton-part, ahol a modernizációs elemek (kisvállalkozás, külföldi tôke jelenléte) egyértelmũen dominálnak. E zónából kiemelkedik Siófok körzete, amely a turizmuson túlmutató, összetettebb gazdaságú.

A régió körzeteinek többsége a modernizációs elemek tekintetében legalább az országos átlagot eléri vagy megközelíti, ugyanakkor minden megyében található egy-egy jellegzetesen agrárkarakterũ mikrokörzet, amely a modernizációt jelzõ átalakulásból 1992. végéig még kimaradt. A Balaton-parti körzetek kiugró vállalkozási aktivitása, Paks hatalmas gazdasági értéktermelô tömege és Pécs nagyvárosi vonzóereje, azaz kifejezetten lokális, kistérségi jegyek ,húzzák" az országos átlag körüli szintre a makrorégió egészét.

\section{A regionális gazdaságfejlesztés irányait érintô következtetések}

Elméletileg és pusztán a területi aggregáció lehetốségeibốl kiindulva bármely nagyobb vagy kisebb térségre készíthetố regionális fejlesztési koncepció. A nagyrégiók esetében azonban mindenképp felteendô a kérdés, hogy valóban olyannyira egyveretũ, gazdaságilag egybeforrott az adott térség, hogy indokolt a fejlesztési koncepcióban egységként kezelni? Ez az elméleti kérdés a dél-dunántúli régió esetében különösen indokolt. Míg az ország más nagyrégiói, akár a válság (Észak-Magyarország), az elmaradottság, a gazdasági karakter (Alföld) vagy épp a megindulóban lévõ dinamika jegyei alapján (Nyugat-Dunántúl és a központi országrész) viszonylagos homogenitást mutatnak, $\mathrm{s}$ így joggal kezelhetôk egységes nagytérségként, addig ez a Dél-Dunántúlra nem mondható el. 


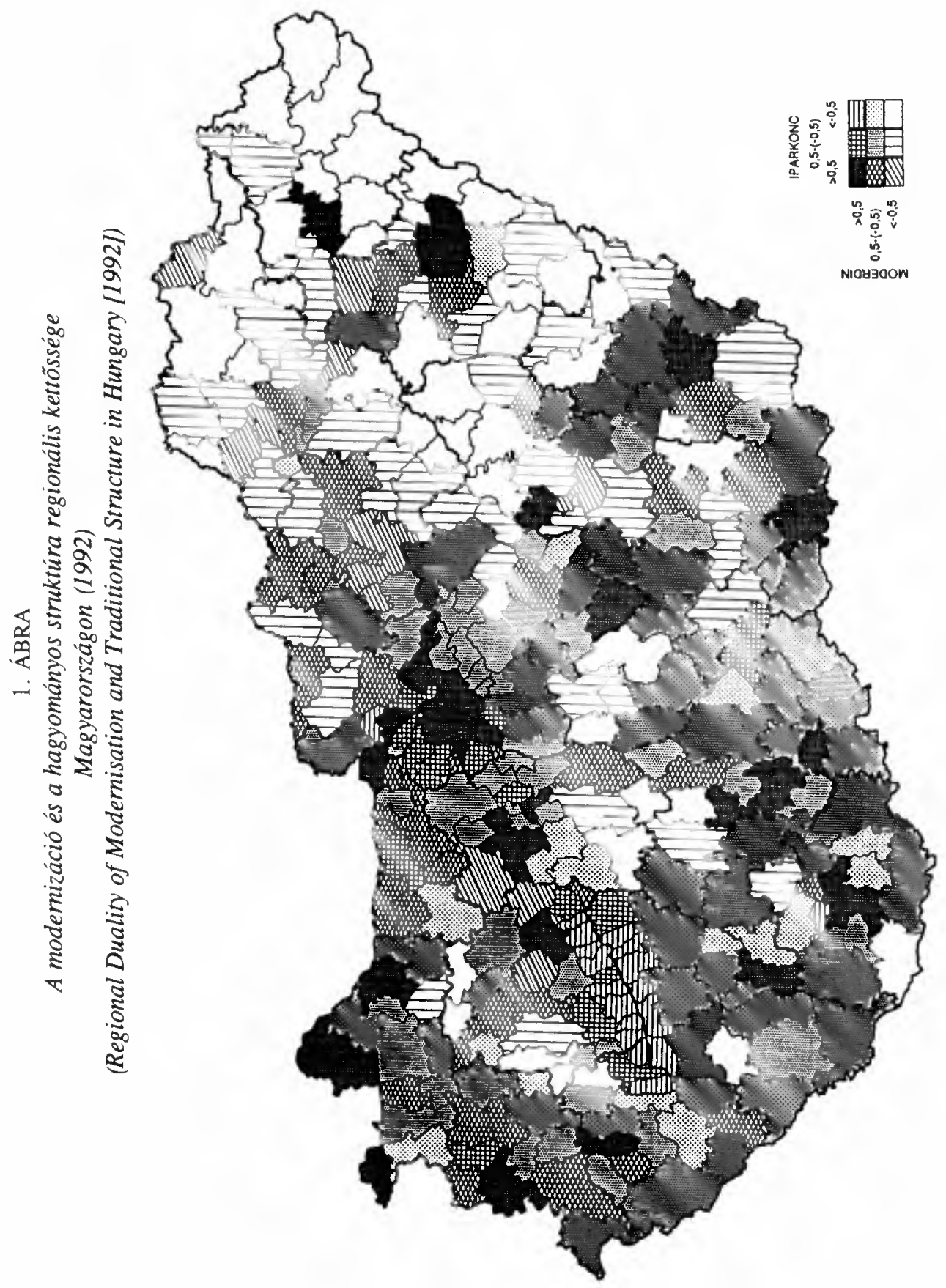


Az összességében átlagos gazdasági mutatókkal rendelkezõ Dél-Dunántúl az ország (gazdasági tekintetben) legheterogénebb nagytérsége, s ezért regionális gazdaságfejlesztési koncepciója csak nagyon eltérõ térségtípusok eltérố irányultságú fejlesztési elképzeléseibõl állhat össze. Ennek nem kell feltétlenül azt jelentenie, hogy minden mikrokörzetre önálló térségfejlesztési koncepció készüljön. A Balaton környék, valamint a határmenti agrárrégiók és a Somogy - Tolna közi belsổ agrárperiféria szinte kínálja magát az egységes koncepcióhoz. A tagoltság és többközpontúság miatt nehezen képzelhetố el egységes fejlesztési koncepció Zala megyére. Felvethetố a Duna-menti zóna önálló térségként való kezelésének végiggondolása is.

A nagyrégió szintjén az is mérlegelendô, hogy a különbözõ fejlôdési pályák mentén haladó kistérségek hatnak-e, $s$ miként egymásra, a fejlốdés a régió egységesülése vagy tagoltságának erősödése irányába mutat-e? Elméletileg nem csak az vethető fel, hogy ezen alternatívának melyik eleme reális, hanem az is, hogy melyik tũnik kívánatosnak, hisz egy ilyenfajta célmeghatározáshoz konkrét gyakorlati következmények párosulnak.

A régió adott gazdasági reálstruktúrájának irányítási szempontból egy többközpontú regionális fejlesztési intézményrendszer felel meg. A régióban a jelzett tagoltság miatt nem egyértelmũ a regionális fejlesztésben a megyei szint középszintként való kizárólagos szerepeltetése sem. Valamifajta egységes regionális fejlesztési „,csúcsszerv" létrehozásának gondolatát és lehetséges funkcióit is alaposan meg kell fontolni a DélDunántúlon.

A belsố heterogenitás a régióban a külsỗ kapcsolatok tekintetében a nyitottság és az elzártság sajátos kettốsségével párosul. A régió határai mentén fekvõ térségek egy része a szomszédos nagyrégiók hasonló karakterũ térségeihez kapcsolódik, illetve velük rokonítható (Balaton-part, Somogy és Tolna északi agrártérségei). Ugyanakkor a déli határszakasz külsô kapcsolatai politikai okokból blokkoltak, keleten a Duna ma még - a szükséges infrastrukturális kapcsolatrendszer hiján - éles határvonalat képez. A zalai térség a zártság-nyitottság dichotómiája vonatkozásában maga is sokarcú. A régió belsõ térségei zártak, a nagy centrumokhoz (Pécs, Kaposvár) kötôdnek. A ,,kifelé” kötôdố zónák esetében a régió más térségeihez való kapcsolódás, a ,,befelé" kényszerült területeknél pedig a külsô kapcsolatrendszert javító fejlesztési irány jelentene a mai helyzethez viszonyítva fordulatot. Ezeket az alternatívákat, lehetôségeket értékmentesen kell végiggondolni. A kapcsolatrendszernek a régió egésze és egyes térségei jövôjét meghatározó kulcsszerepe egyben felveti a régió rendkivül erôs függését a nem kifejezetten területfejlesztési tényezốktôl (az infrastrukturális nagyhálózatok fejlesztésének országos prioritásai és ütemezése, külpolitikai determinációk).

A régió gazdasági térszerkezetére - a Balaton menti településláncot kivéve - jellemzõ tér- és településhálózat-szervezôdési jegyet jelentenek a viszonylag nagy gazdasági erejũ (ugyanakkor bizonytalan helyzetũ) központok és az agrárkarakterũ, széttagolt, kis gazdasági erejü perifériák együttesei. Ez a helyzet a régióban mindenütt felveti a központ-periféria dichotómia regionális politikai kezelésének problémáját, s a mai folyamatok alapján egy erôsödô települési polarizációt jelez elôre kistérségi szinten 
is. A Dél-Dunántúl regionális fejlesztési koncepciójának kidolgozásakor - a kistérségi karakterisztikumok mellett - ezt a településhálózati dimenziót gazdasági oldalról önállóan is feltétlenül végig kell gondolni (másként fogalmazva: regionális településhálózatfejlesztési elképzelések végiggondolása, esetleg kidolgozása is szükségesnek látszik).

A régió egyértelmúen kiemelkedố centruma Pécs (a térség gazdasági potenciáljának mintegy egynegyede összpontosul itt). A város azonban a térségben periférikus helyzetú. Ez az egyik - ha nem is legalapvetôbb - tényezôje a régió belsố tagoltságának, $\mathrm{s}$ a kohézió hiányának is. Gazdaságfejlesztési szempontból sem reálisnak, sem indokoltnak nem látszik az, hogy a városhoz a régió egészére kiterjedố irányító, gazdaságszervezô funkciót rendeljenek valamifajta kiemelt preferenciarendszer segítségével.

Tény, hogy a Dél-Dunántúl egészére jellemzó gazdasági mutatók az országos átlaghoz közeli, a keleti és északi országrésznél egyértelmúen kedvezôbb gazdasági szituációt jeleznek. Ezek alapján makroregionális szempontból nehezen indokolható a régió egészének kiemelt központi regionális politikai kezelése (támogatása). Ez a tény is azt az irányt erỗíti, hogy a térség fejlesztését kistérségi, zonális programok alapján célszerũ végiggondolni, mert egyes térségekben így lehet esély a központi támogatások megszerzésére. A kistérségi közelítés kapcsán mindenképp érdemes emlékeztetni arra, hogy az Alföld és Észak-Magyarország ezzel szemben sokkal inkább olyan karakterũ, hogy lényegében a két nagyrégió egészét átfogó egységes fejlesztési program, illetve támogatási rendszer nélkül, pusztán csak kistérségi fejlesztési bázison felzárkóztatásuk irreális.

Mindez általános érvénnyel igazolja, hogy a kistérség versus makrorégió mint kétfajta regionális fejlesztési stratégiai hangsúly nem egymással szemben, hanem egymás mellett, egyidejūleg kell, hogy szerepet kapjon az ország egészét átfogó regionális politikában. Ezen belül a Dél-Dunántúl fejlesztése, fejlốdése sajátos, esetenként egyedi kistérségi pályákon haladhat, amelyeket azonban minden térségben össze kell, hogy kapcsoljon a gazdasági struktúra modernizálódása. E folyamaton belül egyes zónákban elsôrendũ prioritást kell kapnia az ökológiai szempontnak. Az a tény, hogy a régió vélhetôen nem számíthat nagy volumenư és hatású központi állami regionális támogatásra, egyértelmũen felértékeli a helyi kezdeményezések innovativitás szerepét, amelytôl nagyban függhet az, hogy a régió a jövooben közelít-e az ország legdinamikusabb térségeihez vagy inkább elszakad azoktól, s a pangó gazdaságú térségek közé csúszik.

\section{Jegyzetek}

1 Nemes Nagy J. (1993) Regional Dimensions of the Hungarian Economic Transformation. In: Hajdú Z. (szerk.) Hungary: Society, State, Economy and Regional Structure in Transition, CRS, Pécs, 281. o. 


\title{
SOUTH TRANSDANUBIA ON ITS WAY TOWARDS THE MARKET ECONOMY
}

\author{
JÓZSEF NEMES NAGY
}

The large region covering four counties (Baranya, Somogy, Tolna, Zala) concentrates about one tenth of the Hungarian economic potential. According to indexes that reflect the economic situation the region has a economic state comparible with the national average in the early 1990s. Its situation is much more favourable than that of the Eastern and Northern part of the country, but less favourable than that of North Transdanubia and the central region, including Budapest. This position is justified by many economic indices: division of new enterprises, joint ventures and their economic indices, taxable earnings, unemployment form the base of analysis. By all these, through factor-analysis we can show the presence of both economic modernisational tendencies and of the traditional economic structure. In South Transdanubia we can find small regions with totally different economic characters. County seats emerge in all the counties in matters of economic strength, this is especially true of Pécs, the most important centre of the region, a zone clearly specialised for tourism, besides Lake Balaton. The agrarian regions with many tiny villages are also dominant. The region has a special economic "enclave", Paks, where the only Hungarian nuclear power station was sited. The Mecsek Hills coal mining (Komló) shows features of features. The long term regional development concept of South Transdanubia would be made up from the concepts of the specific small regions. The region cannot rely on a substantial central state support in the future, either, and this give the local initiatives and innovation the most important role.

Translated by Zoltán Raffay 
Tér és Társadalom 8. évf. 1994/1-2. 36. p.

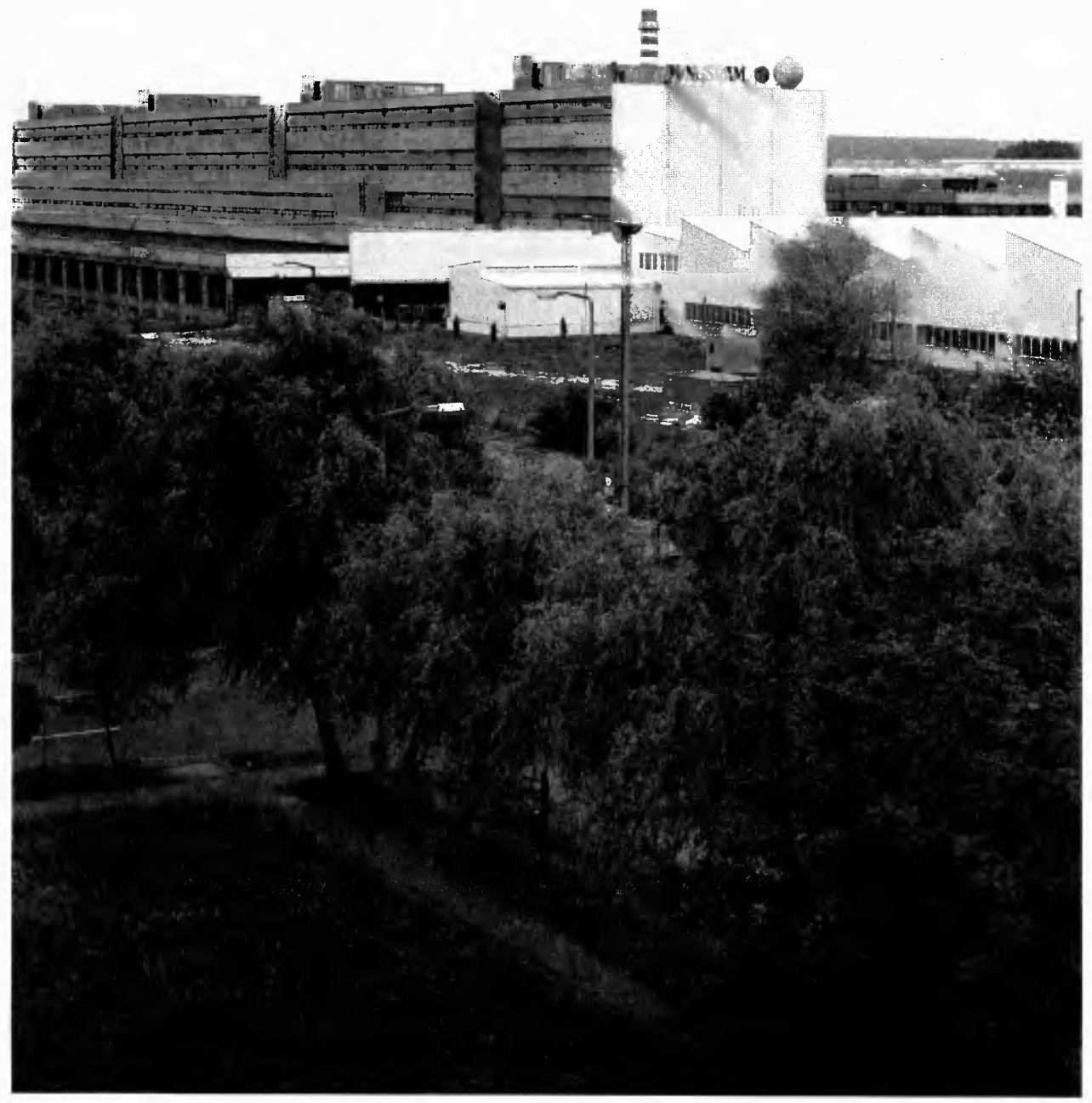

Tungsram Rt., Nagykanizsa (Kotnyek I.) 